\title{
Assessment of the Distribution of the Street Trees of Suwon City for Biodiversity
}

\author{
Choi, Sun $\mathrm{A}^{*} \cdot$ Kim, Shin Won ${ }^{* *}$ \\ *Dept. of Landscape Architecture, master's course, KyungHee Univ., South Korea (tjsk28@khu.ac.kr) \\ ** Corresponding author, Dept. of Landscape Architecture, KyungHee Univ., South Korea (kimsw@khu.ac.kr)
}

\section{A B S TRACT}

This research is about analysis and evaluation of biodiversity of Suwon's street tree, then understanding the problem of it and finally finding a solution. Because the increasing damage of the street trees by disease and insects, insecticide is applied to prevent further damage. However, this insecticide is found to be cancer genic and causing hygienic threat to civilians. Therefore, by gathering Suwon's internal statistics about Suwon's street tree, the trees are divided into three categories, tall evergreen trees, deciduous trees, shrubs following Frank's 30-20-10 theory(1990). Also, according to species diversity index, the problem of disease and insect is researched in terms of biodiversity, and here we suggests solutions to counter such problems.

According to the results, the trees planted in Suwon was found to be 31 families, 43 genus and 58 species. The most used kinds, almost $85 \%$ of the whole species, are found to be Rhododendron indicum (L.) Sweet, Buxus koreana Nakai ex Chung \& al, Euonymus japonicus Thunb, Ligustrum obtusifolium Siebold \& Zucc. Besides these, the rest of $15 \%$ of street trees had little variety. Therefore, it is necessary to plant tree variously and equally in terms of biodiversity. If this Frank's 10-20-30 solution is not enough to completely solve coulure problem, then further research will be done on soil properties, and local features for improvement of Suwon street tress.

(C) 2014 KIEAE Journal

\section{KEYW O R D}

\section{street tree}

Shannon-Weiner species diversity index

evenness index

\section{Introduction}

\subsection{Purpose and Background of the study}

The proliferation of air pollution in urban environment and the increased demand for leisure life due to the enhancement of the life standard of the citizens living in them, the demand and the awareness on the importance of the green areas in the city is advancing. However, the green areas in cities are split up or diminishing rapidly due to a number of development products going on everywhere in the country. For this, the cities have been relying on planting street trees to provide cozy and safety living environment as well as to protect the citizens from possible disasters. $^{1)}$

As far as the street trees are concerned, it is important to select suitable species of trees that could grow successfully in the urban environments. However, since the selection of the street trees currently being plant is limited a handful of them, these tress are not functioning as desired in terms of preventing environmental damages and pests.

According to the statistics of the Bureau of Forestry, the spices of street trees planted in Korea are mainly composed of cherry blossoms $(25 \%$, ginkgo(17.9\%), and maple trees(6.8\%), showing a heavy emphasis on cherry blossoms and ginkgo. This makes them highly vulnerable against a possible threat of pests, which could increases the magnitude of damages geometrically.

One of the most profound cases of such disasters is Dutch elm disease. Due to the invariant selection of trees planted in the affected area, not a single one of them could be free from the influence of the disease. The damage was beyond catastrophic. In case of Korea, cheonan, which invariably selected a single species for the street trees, had more than half of the street trees in the city affected by pests, requiring urgent management of the trees.

As a means to cope with the threats from pests, Korea uses insecticides. However, these agents contain Buprofezin and Benomyl, which are carcinogenic, and pose a public health threat to all citizens. $\left.{ }^{2}\right)$

For this reason, we focused our study on the biodiversity of the street trees in Suwon and examined the distribution of different species and the problems involved, based on the concept of 10-20-30 suggested by Frank.S which signified that a proper mix of species of street trees could be highly effective as a biological means to fight pests. With such an examination, in this study, we

1) Lee, kyu-wan, chin, Sang-chul(1998), The Study on the Methods of Selection for Increase in Diversity of street trees, Journal of Environmental Research, Vol.3 No.1, pp.2 2) Kyounggi Ilbo, "Carcinogenic Pesticide on street trees Invokes Fear,"Nov. 2, 2013 
also proposed a solution for the problems the city currently faces to contribute to the progress of the field of street tree management.

\subsection{Study trends}

The studies on the biodiversity of street trees is more active in foreign countries than in Korea. In case of Korea, Seongjin Yoon (2012) studied the occurrence of pests in street trees of Suwon for all of its species over a period of 5 months. The result showed that 27 species suffered 27 different diseases and 21 different types of pests. The species that suffered the heaviest damages were Rosa multiflora Thunb. var. platyphylla Thory and conifers. On the other hand, Sophora japonica L. or Chionanthus retusus Lindl. \& Paxton were virtually free from such damages.

Gyoungjae Lee (1996) examined the status of the street trees and the problems related to the management of them in Korea with a focus on the cities of Seoul and Incheon. His study showed that there were 66 different species planted in those cities. However, the share of those outside of the top 5 species were only $3 \%$ combined, which was posing a problem. Also, his study mentioned that the contents of organic matters and water in the soil on which the trees were growing was not sufficient to support proper growth of them. As a result, his suggested several solutions to cope with such problems, emphasizing that the most important element of solution was consistent management of them.

Frank Santamour's study on trees for urban planting showed that ensuring diversity of the species planted as street trees could significantly reduce the damages inflicted by pests, emphasizing the importance of biodiversity for the street trees in preventing massive losses of street trees and ensuring protection from new diseases that could be introduced from foreign countries.

In case of Tokyo, the share of Ginkgo and Platanus occidentalis L. until 1960s, which triggered a significant debated. Since then, however, they make sure no single species would exceed $10 \%$ in its share among the total population of street trees, introducing new laws and regulations to ensure biodiversity of street trees in the city.

\section{Study procedure}

\subsection{Target Area}

The special area of the study was the entire city of Suwon, Kyounggi-do. Suwon was the hub of sea transportation in the past and now enjoys a highly convenient network of national highways connecting it with other major cities of the country, such as Kyounggbu, Youngdong, Shingal-Ansan Highway, Euiweon-Asan Highway, and Gyoungbu railway, etc. In the city, quite a number of pedestrians and drivers, as well as other users are using the street trees.3)

3) Gwak, No-jun(2010), A Study on the Urbanscape improvement direction by gilscape and

\subsection{Study process and method}

The processes of this study was as follows; firstly, I examined the existing literature to identify the necessity of this study. Then, based on the data received from the Landscaping Architecture Department of Suwon city, I firstly divided the roads into 'gil,' 'ro,' and 'etc' depending on the characteristics of the road. Then, based on the identified species, I presented the results in accordance with the principles in 10-20-30 method of Frank.S. In addition, by utilizing the Shannon-Wiener Diversity Index (SHDI) and Shannon's Evenness index (SHEI), I analyzed the value of biodiversity of the street trees in the city, which was in turn organized in tables using Microsoft Excel 2010.

The SHDI(H') and SHEI(E) calculated in this study were based on the following formula; $\mathrm{ni}=$ the total number of individual species, $\mathrm{N}=$ the total of all species, $\mathrm{pi}=$ relative proportion of a species, $\mathrm{s}=$ total number of all species

$$
\begin{aligned}
& \text { pi }=\frac{n i}{N} \\
& H^{\prime}=-\sum_{S}^{i=1} \text { pi } \log _{2} \text { pi }\left(H^{\prime} \geq 0\right) \\
& E=H^{\prime} / \log _{2} S(1 \geq E \geq 0)
\end{aligned}
$$

The principles of Frank.S is as follows;

1. No single species shall account for more than $10 \%$ of the total population.

2. No single genus shall exceed $20 \%$ of the total population.

3 . No single family shall exceed $30 \%$ of the total population.

\section{Results and Discussions}

\subsection{Distribution of street trees in Suwon}

The total number of street trees planted in the city was 2,105,940 units, which were composed of 31 families, 43 genus, and 58 species.

Gwonsun district had the largest population of street trees in the city with 787,486 trees(37.39\%) planted on its gil, followed by Yeongtong District, which had 716,874 trees(34.04\%.) Jangan Distract had 374,304 trees(17.77\%) and, lastly, Paldal District had the lowest number of street trees, 227,276(10.79\%.)

In case of the types of the roads, the majority of the trees were planted on the 'ro,' followed by the 'gil' and 'etc' types of roads.

The most representative species on the gil were Rhododendron indicum (L.) Sweet, Buxus koreana Nakai ex Chung \& al, Euonymus japonicus Thumb, Ligustrum obtusifolium Siebold \& Zucc. which accounted for $85 \%$ combined.

view corridor in case of Su-won city, Gangnam University Master Thesis, pp.45 
Table 1. species of trees distribution in Suwon-si

\begin{tabular}{|c|c|c|c|c|c|c|}
\hline \multicolumn{7}{|c|}{ Suwon-si } \\
\hline \multirow[b]{2}{*}{ plant } & \multicolumn{2}{|c|}{ ro } & \multicolumn{2}{|c|}{ gil } & \multicolumn{2}{|c|}{ etc. } \\
\hline & $\begin{array}{c}\text { the } \\
\text { number }\end{array}$ & $\%$ & $\begin{array}{c}\text { the } \\
\text { number }\end{array}$ & $\%$ & $\begin{array}{c}\text { the } \\
\text { number }\end{array}$ & $\%$ \\
\hline $\begin{array}{c}\text { tall } \\
\text { evergreen } \\
\text { trees }\end{array}$ & 12,875 & $1.08 \%$ & 3,249 & $0.37 \%$ & 181 & $0.14 \%$ \\
\hline $\begin{array}{c}\text { deciduous } \\
\text { trees }\end{array}$ & 76,151 & $6.40 \%$ & 33,950 & $3.86 \%$ & 2,891 & $2.26 \%$ \\
\hline shrubs & $1,101,143$ & $92.52 \%$ & 843,432 & $95.78 \%$ & 125,082 & $97.60 \%$ \\
\hline total & $1,190,169$ & $100 \%$ & 880,631 & $100 \%$ & 128,154 & $100 \%$ \\
\hline
\end{tabular}

3.2. The roads and the number of species in each district based on the principle of 10-20-30

\section{1) Gwonsun District}

The type of road with the largest variety of families was ro, which had 23 different families. On the other hand, the 'etc' types of roads had the lowest number, 14. Of these three types of roads (gil, ro, and etc), Buxaceae, Celastraceae, Ericaceae, Pinaceae were commonly used within $30 \%$. Of these, the evergreen tree of Pinaceae(approx 90\%) had the highest share.

According to the principles of Frank.S, it was prohibited to have a single family to account for more than $30 \%$. For this reason, 3 families from the gil, 4 families from ro, and 3 families from etc types of road had to be reduced.

The type of road that had the largest variety of genus was ro, which had 30 genus. On the other hand, etc types of the roads had only 15 genus, which was the lowest. Of these roads (gil, ro, and etc) the commonly discovered genus within the $20 \%$ limit were Buxus, Euonymus, Pinus, and Rhododendron. Of these, the evergreen tree of Pinaceae(approx 97\%) had the highest share. According to the principles of Frank.S, it was prohibited to have a single genus to account for more than $20 \%$. For this reason, 5 genus from the gil, 4 genus from ro, and 3 genus from etc types of road had to be reduced.

The type of road with the largest variety of species was ro, which had 37 different species. On the other hand, etc types of roads had the lowest in number, which was 15 . Of the three types of the roads (gil, ro, and etc), the number of commonly found species within the limit of $10 \%$ were 13 , namely japonicus, biloba, buergerianum, densiflora, glyptostroboides, indicum, koreana, palustris, retusus, schlippenbachii, serrata, turbinata, and yedoense. Of these, densiflora was the highest in ratio. According to the principles of Frank.S, it was prohibited to have a single species to account for more than $10 \%$. For this reason, 10 species from the gil, 10 species from ro, and 6 species from etc types of road had to be reduced.

\section{2) Youngtong District}

The type of road with the largest variety of families was the gil, which had 20 different families. On the other hand, the 'etc' types of roads had the lowest number, 7 .

Of these, the most commonly used families within the $30 \%$ limit were, respectively, Celastraceae, Ulmaceae, and Oleaceae. Of these, Celastraceae had the highest share in all, accounting for $52 \%$. Next in the list was Oleaceae, which was $34 \%$. According to the principles of Frank.S, it was prohibited to have a single family to account for more than $30 \%$. For this reason, 4 families from the gil, 4 families from ro, and 2 families from etc types of road had to be reduced.

The type of road with the largest variety of genus was the gil, which had 27 genus. On the other hand, the 'etc' types of roads had the lowest number, 7.

In the three types of the roads, the most commonly used genus within the limit of $20 \%$ were, respectively, Chionanthus, and Euonymus. Of these, the largest in share was Euonymus, which accounted for $53 \%$. Next up in the list was Chionanthus. According to the principles of Frank.S, it was prohibited to have a single genus to account for more than $20 \%$. For this reason, 5 families from the gil, 4 families from ro, and 3 families from etc types of road had to be reduced.

The type which had the largest number of species was the gil, which had 33 different species. The type with the lowest number of species was the 'etc,' which only had 7. The number of the commonly used species within the $10 \%$ limit was 5 , namely japonica, japonicus, koreana, retusus, and serrata. Of these, japonicus had the majority share, accounting for $50 \%$. It was followed by retusus and serrata, accounting for $23 \%$. According to the principles of Frank.S, it was prohibited to have a single species to account for more than $10 \%$. For this reason, 9 species from the gil, 8 species from ro, and 6 species from etc types of road had to be reduced.

\section{3) Jangan District}

The type of road with the largest variety of families was the gil, which had 16 different families. On the other hand, the 'etc' types of roads had the lowest number, 3. The commonly used families within the $30 \%$ limit were Oleaceae and Ulmaceae. Of these, Oleaceae had the largest share of all, accounting for $50 \%$. It was followed by Ulmaceae, accounting for $32 \%$. According to the principles of Frank.S, it was prohibited to have a single family to account for more than $30 \%$. For this reason, 5 families from the gil, 4 families from ro, and 2 families from etc types of road had to be reduced.

The type of road that had the largest variety of genus was ro, which had 18 genus. On the other hand, etc types of the roads had only 3 genus, which was the lowest. There were no commonly used genus within the $20 \%$ limit. However, there were some that were used on the gil and ro. The number of commonly used species was 
4, which were, respectively, Euonymus, Ligustrum, Pinus, and Zelkova. Other than that, there were no overlapping species. According to the principles of Frank.S, it was prohibited to have a single genus to account for more than $20 \%$. For this reason, 5 genus from the gil, 4 genus from ro, and 2 genus from etc types of road had to be reduced.

Of these, the type of the roads which had the largest number of species was the gil, which had 26. The lowest in number was the other type, which had only three. The number of the commonly used species within the limit of $10 \%$ was 3, which were, respectively, retusus, serrata, and yedoensis. Of these, the species that had the largest share was serrata, which accounted for $27 \%$. According to the principles of Frank.S, it was prohibited to have a single species to account for more than $10 \%$. For this reason, 9 species from the gil, 5 species from ro, and 3 species from etc types of road had to be reduced.

\section{4) Paldal District}

The road type that had the largest number of families was the gil, which had 23 families. And, etc road type had the least, having only 4. The commonly used family within the $30 \%$ limit was Oleaceae, which accounted for $67 \%$, surpassing other trees. Each of the gil, the ro, and etc types had 3 families in excess of the limit presented in Frank.S principle.

The type of the road that had the largest number of genus was the gil, which had 25 . And, the type with the lowest variety was etc type, which had only 4 . Each of the gil and the ro had 4 genus in excess of the limit presented in Frank.S principle, while etc type had 3 genus in excess.

The type that had the largest number of species was the gil, which had 28. etc type had the least, having only 5 . In general, it was confirmed that the 'etc' type of road had the lowest in number. This is believed to be because of the fact that the number of main gil and under roadwork type of roads were smaller in number compared to the other two types (the gil and the ro.) The three commonly used species within the limit of $10 \%$ were koreana, schlippenbachii, and yedoensis. Of these, schlippenbachii had the highest portion, accounting for approx. 22\%. Next up in the list was yedoensis, accounting for $16 \%$. According to the principles of Frank.S, 7 species from the gil, 7 species from ro, and 4 species from etc types of road had to be reduced.

3.3. The suggestions on the number of species based on the types of th e roads and the principle of $10-20-30$

The variety of the species was heavily dependent on a handful of species, signifying a high probability of a catastrophe when an infestation strikes. Therefore, I suggested an alternative mix in accordance with the 10-20-30 principle in order to reduce the probability of such damage. Since there is no guideline for biodiversity of street trees in Suwon, it was assumed that the numbers suggested were the same with the total number of trees that are currently planted. Also, the number of species was determined under the assumption that these numbers should evenly be distributed among the species of which the number of trees is scarce.

The suggestions, therefore, was suggested in the number of threes that satisfies the requirement for each family, genus, and species.

1) The distribution of the suggested tree mixture for Gwonsun District

In terms of the families, Pinaceae accounts for $90 \%$ of the trees. Therefore, the number needs to be reduced. Therefore, 216 trees have to be reduced from the gil, while 7,201 trees have to be reduced from the ro. In 'etc' types of the roads, 127 trees have to be reduced. Also, it is necessary to find an alternative family to replace Pinaceae.

In terms of the genus, a large number of shrubs has to be reduced. Therefore, on the gil, Buxus(25\%) has to be reduced by 18,041 trees, Euonymus(25\%) by 17,873, and Rhododendron(30.6\%) by 37,909 . From the ro, Euonymus(33.2\%) has to be reduced by 42,350 trees and Rhododendron(33.7\%) by 43,752. From the 'etc' type of the roads, Euonymus(67.6\%) has to be reduced by 55,233 trees. The reduced trees have to be replaced with other trees of which the current share is scarce.

In case of the species, the number of evergreen trees in the gil was smaller than desirable. Therefore, 7 more species need to be

Table 2. Distribution of street tree according to family in Gwonseon District.

\begin{tabular}{|c|c|c|c|c|c|}
\hline \multirow{2}{*}{ road } & \multirow{2}{*}{ plant } & $>30.1(\%)$ & \multirow{2}{*}{$\begin{array}{l}\text { Available } \\
\text { street tree }\end{array}$} & \multirow{2}{*}{$\begin{array}{l}\text { Decrease } \\
\text { street tree }\end{array}$} & \multirow{2}{*}{$\begin{array}{l}\text { suggested } \\
\text { street tree }\end{array}$} \\
\hline & & Family & & & \\
\hline \multirow{3}{*}{ gil } & $\begin{array}{c}\text { tall } \\
\text { evergreen } \\
\text { trees }\end{array}$ & Pinaceae & 316 & 216 & 100.5 \\
\hline & $\begin{array}{l}\text { deciduous } \\
\text { trees }\end{array}$ & Rosaceae & 4,723 & 1,137 & $3,586.2$ \\
\hline & shrubs & Ericaceae & 109,660 & 2,034 & $107,626.5$ \\
\hline \multirow{4}{*}{ ro } & $\begin{array}{c}\text { tall } \\
\text { evergreen } \\
\text { trees }\end{array}$ & Pinaceae & 10,307 & $7,209.5$ & $3,097.5$ \\
\hline & $\begin{array}{l}\text { deciduous } \\
\text { trees }\end{array}$ & Cornaceae & 33,511 & $15,326.2$ & $18,184.8$ \\
\hline & \multirow{2}{*}{ shrubs } & Celastraceae & 106,431 & $10,308.9$ & \multirow{2}{*}{$96,122.1$} \\
\hline & & Ericaceae & 107,833 & $11,710.9$ & \\
\hline \multirow{3}{*}{ etc. } & $\begin{array}{c}\text { tall } \\
\text { evergreen } \\
\text { trees }\end{array}$ & Pinaceae & 181 & 126.7 & 54.3 \\
\hline & $\begin{array}{l}\text { deciduous } \\
\text { trees }\end{array}$ & Oleaceae & 1,292 & 549.2 & 742.8 \\
\hline & shrubs & Celastraceae & 78,840 & $43,629.8$ & $34,810.2$ \\
\hline
\end{tabular}


Table 3. Distribution of street tree according to Genus in Gwonseon District.

\begin{tabular}{|c|c|c|c|c|c|}
\hline \multirow{2}{*}{ road } & \multirow{2}{*}{ plant } & $>20.1(\%)$ & \multirow{2}{*}{$\begin{array}{l}\text { Available } \\
\text { street tree }\end{array}$} & \multirow{2}{*}{$\begin{array}{l}\text { Decrease } \\
\text { street tree }\end{array}$} & \multirow{2}{*}{$\begin{array}{l}\text { suggested } \\
\text { street tree }\end{array}$} \\
\hline & & Genus & & & \\
\hline \multirow{5}{*}{ gil } & $\begin{array}{c}\text { tall } \\
\text { evergreen } \\
\text { trees }\end{array}$ & Pinus & 316 & 249 & 67 \\
\hline & $\begin{array}{l}\text { deciduous } \\
\text { trees }\end{array}$ & Prunus & 4,723 & 2,332 & $2,390.8$ \\
\hline & \multirow{3}{*}{ shrubs } & Buxus & 89,792 & 18,041 & \multirow{3}{*}{71,751} \\
\hline & & Euonymus & 89,624 & 17,873 & \\
\hline & & Rhododendron & 109,660 & 37,909 & \\
\hline \multirow{4}{*}{ ro } & $\begin{array}{c}\text { tall } \\
\text { evergreen } \\
\text { trees }\end{array}$ & Pinus & 10,307 & 8,242 & 2,065 \\
\hline & $\begin{array}{c}\text { deciduous } \\
\text { trees }\end{array}$ & Cornus & 33,511 & 21,388 & $12,123.2$ \\
\hline & \multirow{2}{*}{ shrubs } & Euonymus & 106,431 & 42,350 & \multirow{2}{*}{$64,081.4$} \\
\hline & & Rhododendron & 107,833 & 43,752 & \\
\hline \multirow{3}{*}{ etc. } & $\begin{array}{c}\text { tall } \\
\text { evergreen } \\
\text { trees }\end{array}$ & Pinus & 181 & 145 & 36.2 \\
\hline & $\begin{array}{c}\text { deciduous } \\
\text { trees }\end{array}$ & Chionanthus & 1,292 & 797 & 495.2 \\
\hline & shrubs & Euonymus & 78,440 & 55,233 & $23,206.8$ \\
\hline
\end{tabular}

Table 4. Distribution of street tree according to species in Gwonseon District.

\begin{tabular}{|c|c|c|c|c|c|}
\hline \multirow{2}{*}{ road } & \multirow{2}{*}{ plant } & $>10.1(\%)$ & \multirow{2}{*}{$\begin{array}{l}\text { Available } \\
\text { street tree }\end{array}$} & \multirow{2}{*}{$\begin{array}{l}\text { Decrease } \\
\text { street tree }\end{array}$} & \multirow{2}{*}{$\begin{array}{l}\text { suggested } \\
\text { street tree }\end{array}$} \\
\hline & & species & & & \\
\hline \multirow{10}{*}{ gil } & \multirow{2}{*}{$\begin{array}{l}\text { tall } \\
\text { evergreen } \\
\text { trees }\end{array}$} & densiflora & 282 & 248.5 & \multirow[b]{2}{*}{33.5} \\
\hline & & strobus & 34 & 0.5 & \\
\hline & \multirow{4}{*}{$\begin{array}{c}\text { deciduous } \\
\text { trees }\end{array}$} & biloba & 1,581 & 385.6 & \multirow{4}{*}{$1,195.4$} \\
\hline & & retusus & 1,378 & 182.6 & \\
\hline & & serrata & 2,266 & $1,070.6$ & \\
\hline & & yedoensis & 3,536 & $2,340.6$ & \\
\hline & \multirow{4}{*}{ shrubs } & japonicus & 74,024 & $38,148.5$ & \multirow{4}{*}{$35,875.5$} \\
\hline & & indicum & 89,280 & $53,404.5$ & \\
\hline & & koreana & 90,170 & $54,294.5$ & \\
\hline & & obtusifolium & 64,440 & $28,564.5$ & \\
\hline \multirow{7}{*}{ ro } & $\begin{array}{c}\text { tall } \\
\text { evergreen } \\
\text { trees }\end{array}$ & densiflora & 10,303 & $9,270.5$ & $1,032.5$ \\
\hline & \multirow{2}{*}{$\begin{array}{l}\text { deciduous } \\
\text { trees }\end{array}$} & kousa & 33,511 & $27,449.4$ & \multirow{2}{*}{$6,061.6$} \\
\hline & & palmatum & 10,214 & $4,152.4$ & \\
\hline & \multirow{4}{*}{ shrubs } & japonicus & 90,831 & $58,790.3$ & \multirow{4}{*}{$32,040.7$} \\
\hline & & koreana & 32,958 & 917.3 & \\
\hline & & schlippenbachii & 107,680 & $75,639.3$ & \\
\hline & & serrata & 57,520 & $25,479.3$ & \\
\hline \multirow{6}{*}{ etc. } & $\begin{array}{l}\text { tall } \\
\text { evergreen } \\
\text { trees }\end{array}$ & densiflora & 181 & 162.9 & 18.1 \\
\hline & \multirow{3}{*}{$\begin{array}{c}\text { deciduous } \\
\text { trees }\end{array}$} & palustris & 377 & 129.4 & \multirow{3}{*}{247.6} \\
\hline & & retusus & 1,292 & $1,044.4$ & \\
\hline & & yedoensis & 268 & 20.4 & \\
\hline & \multirow{2}{*}{ shrubs } & japonicus & 78,440 & $66,836.6$ & \multirow{2}{*}{$11,603.4$} \\
\hline & & koreana & 11,924 & 320.6 & \\
\hline
\end{tabular}

introduced. In terms of deciduous trees, the biloba has to be reduced by 386 trees, the retusus by 183 , the serrata by 1,071, and the yedoensis by 2,341. Of the shrubs, 35,876 trees should be removed, while the reduced trees are to be replaced with other species.

In ro, 10 more evergreen species were needed. Of the deciduous trees, two species accounted for $70 \%$ of all deciduous trees. Therefore, one species should be reduced by 6,062 trees. In terms of the shrubs, maximum 32,040 trees for a single species would be sufficient.

Finally, for the 'other' type of the roads, the densiflora(100\%, of the evergreen trees, accounted for the entire evergreen trees. Therefore, a maximum of 18 trees would be sufficient. In terms of the deciduous trees, 248 trees for a single species would be sufficient. In case of the japonicus, 66,837 trees has to be reduced, while the Koreana should be reduced by 321 .

In conclusion, the suggestions made in this study are as shown in table 2,3 , and 4 .

\section{2) Distribution species suggested for Yeongtong District}

In case of the 'families' when compared to the deciduous trees in the gil, there was no family that accounted for more than $30 \%$ of the total population. This indicates that the tree mix of this type of road is much more evenly distributed. However, The gaps between the species of the largest numbers and those with the lowest number were still significant, signifying that further efforts are needed to enhance the balance of the mixture.

On the other hand, the number of families was not as high in the 'etc' type of the roads compared to others. And, it turned out that they completely lacked any evergreen trees. In case of deciduous trees and shrubs, Oleaceae and Celastraceae were in excess of the limit. Therefore, each of them require a reduction of 24 trees and 3,586 trees, respectively.

In case of the mixture of genus, the number of trees should be reduced as suggested in Table 6. Especially, tall evergreen trees were found in the 'etc' type of trees, which require more of these types to be planted.

Table 5. Distribution of street tree according to family in Yeongtong District.

\begin{tabular}{|c|c|c|c|c|c|}
\hline \multirow{2}{*}{ road } & \multirow{2}{*}{ plant } & $>30.1$ & \multirow{2}{*}{$\begin{array}{l}\text { Available } \\
\text { street tree }\end{array}$} & \multirow{2}{*}{$\begin{array}{l}\text { Decrease } \\
\text { street tree }\end{array}$} & \multirow{2}{*}{$\begin{array}{l}\text { suggested } \\
\text { street tree }\end{array}$} \\
\hline & & Family & & & \\
\hline \multirow{4}{*}{ gil } & \multirow{2}{*}{$\begin{array}{c}\text { tall } \\
\text { evergreen } \\
\text { trees }\end{array}$} & Pinaceae & 1,066 & 516.4 & \multirow{2}{*}{549.6} \\
\hline & & Taxaceae & 624 & 74.4 & \\
\hline & \multirow{2}{*}{ shrubs } & Celastraceae & 105,240 & $39,176.1$ & \multirow{2}{*}{$66,063.9$} \\
\hline & & Oleaceae & 71,669 & $5,605.1$ & \\
\hline \multirow{4}{*}{ ro } & $\begin{array}{c}\text { tall } \\
\text { evergreen } \\
\text { trees }\end{array}$ & Pinaceae & 1,071 & 749.4 & 321.6 \\
\hline & $\begin{array}{l}\text { deciduous } \\
\text { trees }\end{array}$ & Ulmaceae & 3,703 & $1,399.3$ & $2,303.7$ \\
\hline & \multirow{2}{*}{ shrubs } & Celastraceae & 165,900 & $25,895.1$ & \multirow{2}{*}{$140,004.9$} \\
\hline & & Oleaceae & 218,060 & $78,055.1$ & \\
\hline \multirow[t]{2}{*}{ etc. } & $\begin{array}{l}\text { deciduous } \\
\text { trees }\end{array}$ & Oleaceae & 94 & 24.4 & 69.6 \\
\hline & shrubs & Celastraceae & 5,976 & $3,585.6$ & $2,390.4$ \\
\hline
\end{tabular}


Assessment of the Distribution of the Street Trees of Suwon City for Biodiversity

Table 6. Distribution of street tree according to Genus in Yeongtong District.

\begin{tabular}{|c|c|c|c|c|c|}
\hline \multirow{2}{*}{ road } & \multirow{2}{*}{ plant } & $>20.1$ & \multirow{2}{*}{$\begin{array}{l}\text { Available } \\
\text { street tree }\end{array}$} & \multirow{2}{*}{$\begin{array}{l}\text { Decrease } \\
\text { street tree }\end{array}$} & \multirow{2}{*}{$\begin{array}{l}\text { suggested } \\
\text { street tree }\end{array}$} \\
\hline & & Genus & & & \\
\hline \multirow{5}{*}{ gil } & \multirow{2}{*}{$\begin{array}{c}\text { tall } \\
\text { evergreen } \\
\text { trees }\end{array}$} & Pinus & 1,066 & 699.6 & \multirow{2}{*}{366.4} \\
\hline & & Taxus & 624 & 257.6 & \\
\hline & $\begin{array}{l}\text { deciduous } \\
\text { trees }\end{array}$ & Zelkova & 2,095 & 193.8 & $1,901.2$ \\
\hline & \multirow{2}{*}{ shrubs } & Euonymus & 105,240 & $61,197.4$ & \multirow{2}{*}{$44,042.6$} \\
\hline & & Ligustrum & 71,440 & $27,397.4$ & \\
\hline \multirow{4}{*}{ ro } & $\begin{array}{c}\text { tall } \\
\text { evergreen } \\
\text { trees }\end{array}$ & Pinus & 1,071 & 856.6 & 214.4 \\
\hline & $\begin{array}{c}\text { deciduous } \\
\text { trees }\end{array}$ & Zelkova & 3,703 & $2,167.2$ & $1,535.8$ \\
\hline & \multirow{2}{*}{ shrubs } & Euonymus & 165,900 & $72,563.4$ & \multirow{2}{*}{$93,336.6$} \\
\hline & & Ligustrum & 217,420 & $124,083.4$ & \\
\hline \multirow{3}{*}{ etc. } & deciduous & Ulmus & 53 & 6.6 & \multirow{2}{*}{46.4} \\
\hline & trees & Chionanthus & 94 & 47.6 & \\
\hline & shrubs & Euonymus & 5,976 & $4,382.4$ & $1,593.6$ \\
\hline
\end{tabular}

Table 7. Distribution of street tree according to species in Yeongtong District.

\begin{tabular}{|c|c|c|c|c|c|}
\hline \multirow{2}{*}{ road } & \multirow{2}{*}{ plant } & $>10.1$ & \multirow{2}{*}{$\begin{array}{l}\text { Available } \\
\text { street tree }\end{array}$} & \multirow{2}{*}{$\begin{array}{l}\text { Decrease } \\
\text { street tree }\end{array}$} & \multirow{2}{*}{$\begin{array}{l}\text { suggested } \\
\text { street tree }\end{array}$} \\
\hline & & species & & & \\
\hline \multirow{9}{*}{ gil } & \multirow{2}{*}{$\begin{array}{c}\text { tall } \\
\text { evergreen } \\
\text { trees }\end{array}$} & parviflora & 1,066 & 882.8 & \multirow{2}{*}{183.2} \\
\hline & & cuspidata & 624 & 440.8 & \\
\hline & & japonica & 1,067 & 116.4 & \multirow{2}{*}{950.6} \\
\hline & & biloba & 1,575 & 624.4 & \\
\hline & & retusus & 1,368 & 417.4 & \multirow{3}{*}{950.6} \\
\hline & & serrata & 2,095 & $1,144.4$ & \\
\hline & & yedoensis & 1,025 & 74.4 & \\
\hline & \multirow{2}{*}{ shrubs } & japonicus & 98,840 & $76,818.7$ & \multirow{2}{*}{$22,021.3$} \\
\hline & & obtusifolium & 71,440 & $49,418.7$ & \\
\hline \multirow{8}{*}{ ro } & $\begin{array}{c}\text { tall } \\
\text { evergreen } \\
\text { trees }\end{array}$ & densiflora & 1,071 & 963.8 & 107.2 \\
\hline & \multirow{4}{*}{$\begin{array}{l}\text { deciduous } \\
\text { trees }\end{array}$} & biloba & 790 & 22.1 & 767.9 \\
\hline & & glyptostroboides & 892 & 124.1 & \multirow{3}{*}{767.9} \\
\hline & & retusus & 1,285 & 517.1 & \\
\hline & & serrata & 3,703 & $2,935.1$ & \\
\hline & \multirow{3}{*}{ shrubs } & japonicus & 139,400 & $92,731.7$ & \multirow{3}{*}{$46,668.3$} \\
\hline & & koreana & 51,420 & $4,751.7$ & \\
\hline & & obtusifolium & 217,420 & $170,751.7$ & \\
\hline \multirow{6}{*}{ etc. } & \multirow{4}{*}{$\begin{array}{c}\text { deciduous } \\
\text { trees }\end{array}$} & davidiana & 53 & 29.8 & \multirow{4}{*}{23.2} \\
\hline & & japonica & 45 & 21.8 & \\
\hline & & retusus & 94 & 70.8 & \\
\hline & & yedoensis & 40 & 16.8 & \\
\hline & \multirow{2}{*}{ shrubs } & japonicus & 5,976 & $5,179.2$ & \multirow{2}{*}{796.8} \\
\hline & & koreana & 1,260 & 463.2 & \\
\hline
\end{tabular}

As for the species, the shrubs had more reduction compared to etc types of trees (evergreens, deciduous trees.) It is believed that this is because of several species removed in large numbers. For this reason, it is also believed that new trees of different kinds should be planted in order to replace the ones that have been removed.

3) Distribution of the suggested tree mixture in jangan District

In case of the 'families,' the ro needed larger reductions compared to the gil. This means that the proportion of a single
Table 8. Distribution of street tree according to family in Jangan District.

\begin{tabular}{|c|c|c|c|c|c|}
\hline road & plant & $\begin{array}{l}30.1 \\
\text { family }\end{array}$ & $\begin{array}{l}\text { Available } \\
\text { street tree }\end{array}$ & $\begin{array}{c}\text { Decrease } \\
\text { street tree }\end{array}$ & $\begin{array}{l}\text { suggested } \\
\text { street tree }\end{array}$ \\
\hline \multirow{5}{*}{ gil } & \multirow{2}{*}{$\begin{array}{c}\text { tall } \\
\text { evergreen } \\
\text { trees }\end{array}$} & Pinaceae & 546 & 238.5 & \multirow{2}{*}{307.5} \\
\hline & & Taxaceae & 460 & 152.5 & \\
\hline & $\begin{array}{l}\text { deciduous } \\
\text { trees }\end{array}$ & Ulmaceae & 3,008 & 669.2 & 233.8 \\
\hline & shrubs & Celastraceae & 60,520 & $11,876.8$ & \multirow{2}{*}{$48,643.2$} \\
\hline & & Oleaceae & 72,780 & $24,136.8$ & \\
\hline \multirow{4}{*}{ ro } & $\begin{array}{c}\text { tall } \\
\text { evergreen } \\
\text { trees }\end{array}$ & Pinaceae & 1,077 & 71,439 & 362.1 \\
\hline & deciduous & Ginkgoaceae & 2,204 & 978.5 & \multirow{2}{*}{$1,225.5$} \\
\hline & trees & Ulmaceae & 1,284 & 58.5 & \\
\hline & shrubs & Oleaceae & 132,886 & $73,499.8$ & $59,386.2$ \\
\hline & \multirow{2}{*}{$\begin{array}{l}\text { deciduous } \\
\text { trees }\end{array}$} & Oleaceae & 33 & 7.2 & \multirow{2}{*}{25.8} \\
\hline & & Ulmaceae & 41 & 15.2 & \\
\hline
\end{tabular}

Table 9. Distribution of street tree according to Genus in Jangan District.

\begin{tabular}{|c|c|c|c|c|c|}
\hline \multirow{2}{*}{ road } & \multirow{2}{*}{ plant } & $>20.1$ & \multirow{2}{*}{$\begin{array}{l}\text { Available } \\
\text { street tree }\end{array}$} & \multirow{2}{*}{$\begin{array}{l}\text { Decrease } \\
\text { street tree }\end{array}$} & \multirow{2}{*}{$\begin{array}{l}\text { suggested } \\
\text { street tree }\end{array}$} \\
\hline & & Genus & & & \\
\hline \multirow{5}{*}{ gil } & \multirow{2}{*}{$\begin{array}{c}\text { tall } \\
\text { evergreen } \\
\text { trees }\end{array}$} & Pinus & 546 & 341.0 & \multirow{2}{*}{205.0} \\
\hline & & Taxus & 460 & 255.0 & \\
\hline & $\begin{array}{l}\text { deciduous } \\
\text { trees }\end{array}$ & Zelkova & 3,008 & $1,448.8$ & $1,559.2$ \\
\hline & \multirow{2}{*}{ shrubs } & Euonymus & 60,520 & $28,091.2$ & \multirow{2}{*}{$31,428.8$} \\
\hline & & Ligustrum & 72,780 & $40,351.2$ & \\
\hline \multirow{5}{*}{ ro } & $\begin{array}{c}\text { tall } \\
\text { evergreen } \\
\text { trees }\end{array}$ & Pinus & 1,077 & 835.6 & 241.4 \\
\hline & \multirow{2}{*}{$\begin{array}{c}\text { deciduous } \\
\text { trees }\end{array}$} & Ginkgo & 2,204 & $1,387.0$ & \multirow{2}{*}{817.0} \\
\hline & & Zelkova & 1,284 & 467.0 & \\
\hline & \multirow{2}{*}{ shrubs } & Euonymus & 39,636 & 45.2 & \multirow{2}{*}{$39,590.8$} \\
\hline & & Ligustrum & 132,886 & $93,295.2$ & \\
\hline \multirow{2}{*}{ etc. } & \multirow{2}{*}{$\begin{array}{c}\text { deciduous } \\
\text { trees }\end{array}$} & Oleaceae & 33 & 15.8 & \multirow{2}{*}{17.2} \\
\hline & & Ulmaceae & 41 & 23.8 & \\
\hline
\end{tabular}

Table 10. Distribution of street tree according to species in Jangan District.

\begin{tabular}{|c|c|c|c|c|c|}
\hline \multirow{2}{*}{ road } & \multirow{2}{*}{ plant } & $>10.1$ & \multirow{2}{*}{$\begin{array}{l}\text { Available } \\
\text { street tree }\end{array}$} & \multirow{2}{*}{$\begin{array}{l}\text { Decrease } \\
\text { street tree }\end{array}$} & \multirow{2}{*}{$\begin{array}{l}\text { suggested } \\
\text { street tree }\end{array}$} \\
\hline & & species & & & \\
\hline \multirow{9}{*}{ gil } & \multirow{3}{*}{$\begin{array}{c}\text { tall } \\
\text { evergreen } \\
\text { trees }\end{array}$} & cuspidata & 460 & 357.5 & \multirow{3}{*}{102.5} \\
\hline & & densiflora & 251 & 148.5 & \\
\hline & & strobus & 295 & 192.5 & \\
\hline & \multirow{3}{*}{$\begin{array}{l}\text { deciduous } \\
\text { trees }\end{array}$} & biloba & 1,137 & 357.4 & \multirow{3}{*}{779.6} \\
\hline & & glyptostroboides & 842 & 62.4 & \\
\hline & & yedoensis & 1,145 & 365.4 & \\
\hline & \multirow{3}{*}{ shrubs } & japonicus & 59,532 & $43,317.6$ & \multirow{3}{*}{$16,214.4$} \\
\hline & & obtusifolium & 72,780 & $56,565.6$ & \\
\hline & & subsessilis & 16,324 & 109.6 & \\
\hline \multirow{5}{*}{ ro } & $\begin{array}{c}\text { tall } \\
\text { evergreen } \\
\text { trees } \\
\end{array}$ & densiflora & 1,049 & 928.3 & 120.7 \\
\hline & \multirow{2}{*}{$\begin{array}{l}\text { deciduous } \\
\text { trees }\end{array}$} & biloba & 2,204 & $1,795.5$ & \multirow{2}{*}{408.5} \\
\hline & & serrata & 1,284 & 875.5 & \\
\hline & \multirow{2}{*}{ shrubs } & japonicus & 39,636 & $19,840.6$ & \multirow{2}{*}{$19,795.4$} \\
\hline & & obtusifolium & 132,886 & $113,090.6$ & \\
\hline \multirow{3}{*}{ etc. } & \multirow{3}{*}{$\begin{array}{l}\text { deciduous } \\
\text { trees }\end{array}$} & retusus & 33 & 24.4 & \multirow{3}{*}{8.6} \\
\hline & & serrata & 41 & 32.4 & \\
\hline & & yedoensis & 12 & 3.4 & \\
\hline
\end{tabular}

family in ro was higher than that in the gil. It also signifies that the imbalance of the mixture is heavier in ro than it is in the gil. Therefore, I believe they need to give efforts to restore the balance of the mixture. In addition, tall evergreen trees and shrubs were 
planted in the 'etc' types of the roads, which require other types of trees to be planted.

In case of the genus, it was confirmed that a large number of shrubs need to be reduced in the gil and the ro. Therefore, the sufficient number of shrubs in the gil would be 31,429 , and 39,591 for the ro.

In case of species, it was confirmed that a significant reduction was required in terms of the shrubs in the gil and the ro. Therefore, reductions as suggested in table 10 are necessary. It turned out that the 'etc' types of the road did not require any reduction of evergreens and shrubs.

4) Distribution of the suggested tree mixture in Paldal District

As for the families, a comparison of the planted trees revealed that the gap between the ones with higher proportion and those with lower proportions was significant. In case of evergreens and shrubs, the level of diversity was low, and a majority of trees were concentrated in a single family. As for the deciduous trees,

Table 11. Distribution of street tree according to family in Paldal District.

\begin{tabular}{c|c|c|c|c|c}
\hline \multirow{2}{*}{ road } & plant & $>30.1$ & $\begin{array}{c}\text { Available } \\
\text { street tree }\end{array}$ & $\begin{array}{c}\text { Decrease } \\
\text { street tree }\end{array}$ & $\begin{array}{c}\text { suggested } \\
\text { street tree }\end{array}$ \\
\cline { 3 - 5 } gil & $\begin{array}{c}\text { tall } \\
\text { evergreen } \\
\text { trees }\end{array}$ & Pamily & 47 & 29.9 & 17.1 \\
\cline { 2 - 5 } & $\begin{array}{c}\text { deciduous } \\
\text { trees }\end{array}$ & Ginkgoaceae & 1,655 & 246.8 & $1,408.2$ \\
\cline { 2 - 5 } & shrubs & Oleaceae & 63,800 & 33,104 & 30,696 \\
\hline \multirow{7}{*}{ ro } & $\begin{array}{c}\text { tall } \\
\text { evergreen } \\
\text { trees }\end{array}$ & Pinaceae & 219 & 137.7 & 81.3 \\
\cline { 2 - 5 } & $\begin{array}{c}\text { deciduous } \\
\text { trees }\end{array}$ & Ginkgoaceae & 1,326 & 194.7 & $1,131.3$ \\
\cline { 2 - 5 } shrubs & Oleaceae & 80,700 & $45,807.3$ & $34,829.7$ \\
\hline \multirow{2}{*}{ etc. } & $\begin{array}{c}\text { deciduous } \\
\text { trees }\end{array}$ & Oleaceae & 67 & 57.3 & \multirow{2}{*}{9.7} \\
\cline { 2 - 5 } & shrubs & Ericaceae & 1,000 & 324.0 & 676.0 \\
\hline
\end{tabular}

Table 12. Distribution of street tree according to Genus in Paldal District.

\begin{tabular}{|c|c|c|c|c|c|}
\hline \multirow{2}{*}{ road } & \multirow{2}{*}{ plant } & $>20.1$ & \multirow{2}{*}{$\begin{array}{l}\text { Available } \\
\text { street tree }\end{array}$} & \multirow{2}{*}{$\begin{array}{c}\text { Decrease } \\
\text { street tree }\end{array}$} & \multirow{2}{*}{$\begin{array}{l}\text { suggested } \\
\text { street tree }\end{array}$} \\
\hline & & Genus & & & \\
\hline \multirow{4}{*}{ gil } & $\begin{array}{c}\text { tall } \\
\text { evergreen } \\
\text { trees }\end{array}$ & Pinus & 47 & 35.6 & 11.4 \\
\hline & $\begin{array}{l}\text { deciduous } \\
\text { trees }\end{array}$ & Ginkgo & 1,655 & 716.2 & 938.8 \\
\hline & \multirow{2}{*}{ shrubs } & Euonymus & 23,160 & $2,696.0$ & \multirow{2}{*}{$20,464.0$} \\
\hline & & Ligustrum & 63,800 & $43,336.0$ & \\
\hline \multirow{4}{*}{ ro } & $\begin{array}{c}\text { tall } \\
\text { evergreen } \\
\text { trees }\end{array}$ & Pinus & 219 & 164.8 & 54.2 \\
\hline & $\begin{array}{c}\text { deciduous } \\
\text { trees }\end{array}$ & Ginkgo & 1,326 & 571.8 & 754.2 \\
\hline & \multirow{2}{*}{ shrubs } & Ligustrum & 80,700 & $57,480.2$ & \multirow{2}{*}{$23,219.8$} \\
\hline & & Rhododendron & 25,200 & $1,980.2$ & \\
\hline \multirow{3}{*}{ etc. } & deciduous & Chionanthus & 67 & 47.6 & \multirow{2}{*}{19.4} \\
\hline & & Prunus & 30 & 10.6 & \\
\hline & shrubs & Rhododendron & 1,000 & 784.0 & 216.0 \\
\hline
\end{tabular}

Table 13. Distribution of street tree according to species in Paldal District.

\begin{tabular}{|c|c|c|c|c|c|}
\hline \multirow{2}{*}{ road } & \multirow{2}{*}{ plant } & $>10.1$ & \multirow{2}{*}{$\begin{array}{l}\text { Available } \\
\text { street tree }\end{array}$} & \multirow{2}{*}{$\begin{array}{l}\text { Decrease } \\
\text { street tree }\end{array}$} & \multirow{2}{*}{$\begin{array}{l}\text { suggested } \\
\text { street tree }\end{array}$} \\
\hline & & species & & & \\
\hline \multirow{7}{*}{ gil } & \multirow{2}{*}{$\begin{array}{l}\text { tall } \\
\text { evergreen } \\
\text { trees }\end{array}$} & densiflora & 46 & 40 & \multirow{2}{*}{5.7} \\
\hline & & nigra & 6 & 0 & \\
\hline & \multirow{3}{*}{$\begin{array}{l}\text { deciduous } \\
\text { trees }\end{array}$} & biloba & 1,655 & 1,186 & \multirow{3}{*}{469.4} \\
\hline & & serrata & 691 & 222 & \\
\hline & & yedoensis & 716 & 247 & \\
\hline & \multirow{2}{*}{ shrubs } & japonicus & 23,160 & 12,928 & \multirow{2}{*}{$10,232.0$} \\
\hline & & obtusifolium & 63,800 & 53,568 & \\
\hline \multirow{7}{*}{ ro } & \multirow{2}{*}{$\begin{array}{c}\text { tall } \\
\text { evergreen } \\
\text { trees }\end{array}$} & chinensis & 38 & 11 & 27.1 \\
\hline & & densiflora & 219 & 192 & 27.1 \\
\hline & \multirow{3}{*}{$\begin{array}{l}\text { deciduous } \\
\text { trees }\end{array}$} & biloba & 1,326 & 949 & \multirow{3}{*}{377.1} \\
\hline & & buergerianum & 437 & 60 & \\
\hline & & serrata & 734 & 357 & \\
\hline & \multirow{2}{*}{ shrubs } & obtusifolium & 80,700 & 69,090 & \multirow{2}{*}{$11,609.9$} \\
\hline & & schlippenbachii & 25,200 & 13,590 & \\
\hline \multirow{4}{*}{ etc. } & \multirow{2}{*}{$\begin{array}{l}\text { deciduous } \\
\text { trees }\end{array}$} & retusus & 67 & 57 & \multirow{2}{*}{9.7} \\
\hline & & yedoensis & 30 & 20 & \\
\hline & \multirow{2}{*}{ shrubs } & indicum & 600 & 492 & \multirow{2}{*}{108.0} \\
\hline & & schlippenbachii & 400 & 292 & \\
\hline
\end{tabular}

Ginkgoaceae, which are commonly discovered in Korea, turned out be planted in the gil and the ro in large numbers, which required reductions. In the 'etc' types of the roads, a maximum of 10 deciduous trees and 676 shrubs need to be planted.

As for the genus, reductions as specified in table 12 are required. Especially, the number of shrubs needs to be reduced significantly, and it requires other replacements in its place and evenly distributed mixture of trees for that matter.

As for the species, the nigra, which is an evergreen, exceeded the limit slightly in the gil. But, it did not require any reductions. As for the deciduous trees, the biloba, the serrata, and the yedoensis need to be reduced by $1,186,222$, and 247 , respectively. As for the shrubs, the japonicus and the obtusifolium need too be reduced by 12,928 and 53,568 . In the ro, the tall evergreens and the deciduous trees need to be increased by 27 and 377 trees. As for the shrubs, a maximum of 11,610 trees need to be planted. The tall evergreens in the 'etc' types of road did not require any reduction. However, since there were tall evergreen trees, it is believed that the city needs to plant such types of trees.

\subsection{The richness and diversity indices for the street trees of Suwon}

In order to evaluate and suggest the biodiversity within the population, we used Shannon-Weiner's biodiversity index. In case of Gwonsun district, the evenness index showed that the evenness value in the ro of Gwonsun District was lower than that of the gil in the same district. This means that the selection of species in the ro is leaning toward a single species excessively. Of the three types of 
Table 14. Street tree Species richness, diversity index, evenness index in Suwon-si

\begin{tabular}{|c|c|c|c|c|c|c|c|}
\hline \multirow{2}{*}{\multicolumn{2}{|c|}{ Division }} & \multicolumn{2}{|c|}{ ro } & \multicolumn{2}{|c|}{ gil } & \multicolumn{2}{|c|}{ etc. } \\
\hline & & \multirow{2}{*}{$\begin{array}{c}\text { Available } \\
37\end{array}$} & \multirow{2}{*}{$\begin{array}{c}\text { Suggestion } \\
44 \\
\end{array}$} & \multirow{2}{*}{$\begin{array}{c}\text { Available } \\
33\end{array}$} & \multirow{2}{*}{$\begin{array}{c}\text { Suggestion } \\
40\end{array}$} & \multirow{2}{*}{$\begin{array}{c}\text { Available } \\
15 \\
\end{array}$} & \multirow{2}{*}{$\begin{array}{c}\text { Suggestion } \\
34 \\
\end{array}$} \\
\hline \multirow{4}{*}{ Gwonseon-gu } & Number of species & & & & & & \\
\hline & Species richness & 201.33 & 240.48 & 178.22 & 217.21 & 71.04 & 167.46 \\
\hline & diversity index & \multicolumn{2}{|c|}{0.39} & \multicolumn{2}{|c|}{0.42} & \multicolumn{2}{|c|}{1.19} \\
\hline & evenness index & \multicolumn{2}{|c|}{0.075} & \multicolumn{2}{|c|}{0.083} & \multicolumn{2}{|c|}{0.307} \\
\hline \multirow{4}{*}{ Yeongtong-gu } & Number of species & 26 & 34 & 34 & 41 & 7 & 20 \\
\hline & Species richness & 141.93 & 187.34 & 177.03 & 214.59 & 23.48 & 74.36 \\
\hline & diversity index & \multicolumn{2}{|c|}{0.63} & \multicolumn{2}{|c|}{0.59} & \multicolumn{2}{|c|}{1.68} \\
\hline & evenness index & \multicolumn{2}{|c|}{0.134} & \multicolumn{2}{|c|}{0.116} & \multicolumn{2}{|c|}{0.598} \\
\hline \multirow{4}{*}{ Jangan-gu } & Number of species & 18 & 30 & 26 & 33 & 3 & 30 \\
\hline & Species richness & 94.74 & 161.62 & 139.33 & 178.34 & 11.15 & 161.62 \\
\hline & diversity index & \multicolumn{2}{|c|}{1.19} & \multicolumn{2}{|c|}{0.63} & \multicolumn{2}{|c|}{0.77} \\
\hline & evenness index & \multicolumn{2}{|c|}{0.285} & \multicolumn{2}{|c|}{0.134} & \multicolumn{2}{|c|}{0.486} \\
\hline \multirow{4}{*}{ Paldal-gu } & Number of species & 22 & 35 & 28 & 35 & 5 & 30 \\
\hline & Species richness & 112.53 & 182.19 & 144.68 & 182.19 & 21.43 & 155.40 \\
\hline & diversity index & \multicolumn{2}{|c|}{1.27} & \multicolumn{2}{|c|}{0.94} & \multicolumn{2}{|c|}{0.78} \\
\hline & evenness index & \multicolumn{2}{|c|}{0.285} & & & & \\
\hline
\end{tabular}

the roads, the etc types of the roads had the most evenly distributed mixture(0.307), while the richness of the species was significantly lower than those of the other two. Therefore, it is necessarily to increase the number of species deployed in this type of road.

In case of Yeongtong District, the richness of the species was higher in the gil compared to the ro. However, the diversity index value and the evenness index value were lower than those of the ro. In terms of the evenness index, the 'etc' type was the highest in all three. However, in terms of the richness, it was the lowest of all, requiring planting of more species.

As for Jangan District, the gil were higher in terms of the richness. But, the evenness value and the diversity index were lower than those of the ro. Therefore, they need to distribute the planted species more evenly and increase the richness of the species. The type of road that had the highest evenness value was the 'etc' type. However, the diversity index was significantly lower than those of th other two. It should be raised from the current 11.15 to 161.62 .

In case of Paldal District, the ro did not have as many species as the gil. However, the mixture was more evenly distributed compared to the gil. The evenness index was the highest in the 'etc' type of the road. However, they was lower in terms of the richness, which should be raised from the current 21.43 to 155.40 .

The overall evaluation of the biodiversity in the city of Suwon showed that, while the richness was higher, this did not resulted in higher evenness indices. And, even when the evenness was higher, the richness of the species was lower. It is believed that this is because the focus in planting street trees was made mainly on the aesthetic qualifies. Therefore, it is necessary to diversify the species in order to increase the species richness, the diversity index, and the evenness index.

\section{Conclusion}

Thee purpose of this study was, as a means to enhance the health of the users of the street trees and protect the trees from biological threats and pests, to evaluate them in terms of their biodiversity and identify the current problems they face, along with suggestions for solutions and improvements.

For this reason, we collected the distribution data of the street trees and surveyed the distribution of the trees based on the scientific names of the trees in the bio species knowledge data base. Then, the distribution of the trees and Shannon-Weiner's biodiversity index were used to provide possible solutions for improvement. As a result, it turned out that the total number of street trees planted in the city was $2,105,940$ units, which were composed of 31 families, 43 genus, and 58 species.

The result of the analysis of the species distribution based on the principle of 10-20-30, the mixture was heavily dependent on a few, and a significant number of trees were in excess of the limits proposed in the principle. Also, while the number of planted trees was significant, it was revealed that the number of other species than the few was scarce, exposing the entire population to the threat of pests significantly. Therefore, as a means of biological prevention, the selection of the species and even distribution of the mixture need to be considered. This will, in turn, contributed to reduction of pest control costs and enhancement of the health of the citizens.

However, in spite of the significance and implication of this study, it is still true that the 10-20-30 principle alone cannot resolve all pest threats, and additional studies in the future would be necessary, putting the soil and the local environmental factors into consideration. 


\section{Reference}

[1] Gwak, No-jun(2010), A Study on the Urbanscape improvement direction by streetscape and view corrider in case of Su-won city, Gangnam University Master Thesis

[2] Lee, kyung-jae(1996), Maintenance of the city's street tree boulevards Status and Problems of Korea -Focused on the city of Seoul and Incheon-

[3] Lee, kyu-wan, chin, Sang-chul(1998), The Study on the Methods of Selection for Increase in Diversity of Street Trees, Journal of Environmental Research, Vol.3 No.1, pp.2

[4] Yoon, Sung-jin(2012), Study on the observation of disease and insects of street trees in Suwon, Sungkyunkwan University Master Thesis

[5] Li, Zhi-hua(2011), Comparison and Analysis of Street tree in Beijing, China and Daejeon, South Korea : Focused on species diversity and introduction, PaiChai University Master Thesis

[6] Lee, Hoo-nam(1980), study of the plant communities analysis of the Mt. Hanla based on the species diversity index, Ewha Womans University Master Thesis

[7] Baris Kara(2012), Assessment of the distribution and diversity of street tree species in Aydin, Turkey, Journal of Food, Agriculture \& Environment Vol.10 (3\&4): 919-928

[8] Frank S. Santamour(1990), trees for urban planting: diversity uniformity, and common sense, metria 7: proceedings p57-66

[9] http://www.kyeonggi.com/news/articleView.html?idxno=721128

[10] Natural Bio Species Knowledge Data Base(NATURE), http://www.nature.go.kr

[11] Suwon city ebook(2007), an illustrated plant book, Suwon city 